\title{
Mirror-image fossils reveal colony form of extinct Curaçao Isopora
}

Received: 12 January 2009/ Accepted: 25 March 2009/Published online: 18 April 2009

(C) Springer-Verlag 2009

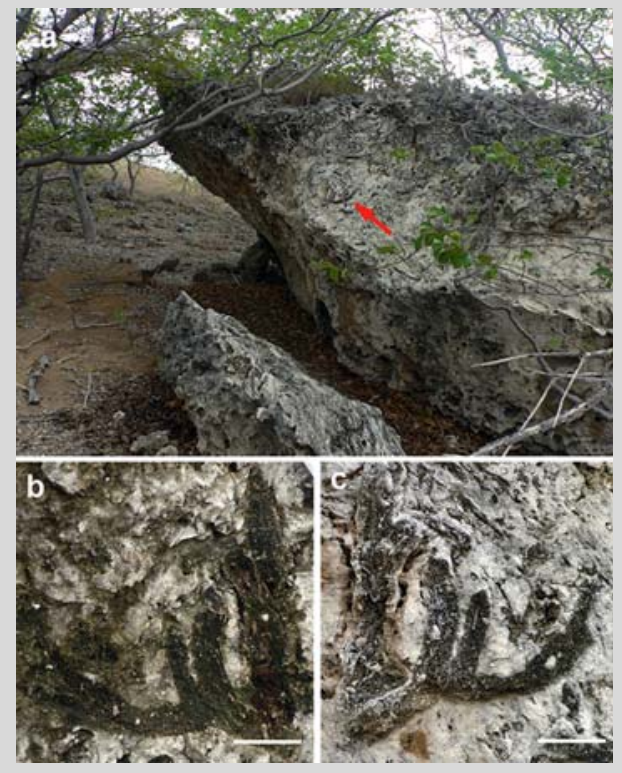

Fig. 1 a Carbonate rock face on Pliocene Ridges at Salina Sint Michiel, Curaçao (Site AB95-77 of Budd et al. 1998). Right-hand image of Isopora curacaoensis sample is shown in the centre of the image (red arrow). b left-hand image from fallen rock face and c right-hand image from intact rock face. Scale bars $50 \mathrm{~mm}$
The extinct Caribbean coral species Isopora curacaoensis Budd and Wallace, 2008 occurred during 6-3 Ma (Mio-Pliocene). It is found in Curaçao, Netherlands Antilles, with its congener Isopora ginsburgi Budd and Wallace, 2008 ( 6-2 Ma). These are the earliest recorded occurrences of Isopora worldwide. Until now Isopora curacaoensis was known only from broken branches, which did not indicate any aspect of overall colony shape.

On a visit to the Salina Sint Michiel, in the Seroe Domi Formation of Curaçao, in July 2008, a large rock with a broken section was found to contain numerous fossils of Isopora curacaoensis, in which the axes of the corallites and some of the coenosteum had been replaced, forming casts. Some of these had been split into left and right mirror-image pieces (Fig. 1). One was a large section of colony (approx. $200 \times 200 \mathrm{~mm}$ ), showing a full branching unit including vertical branch base, horizontally extending branch and a secondary series of vertical branches (Fig. 1b, c), indicating that this colony had an open arborescent or 'candelabra' form, similar to that seen in some living specimens of Isopora togianensis in Sulawesi, Indonesia (Wallace et al. 2007).

The site is dated as early-mid Pliocene, absolute age range of 5.6-3 Ma (Budd et al. 1998). Also found here were the modern Acropora cervicornis and A. palmata, and the extinct A. panamensis. This indicates that conditions favouring both the extinct Caribbean genus Isopora and the successful modern genus Acropora occurred, as today in living Indo-Pacific reefs. At this point in time, Isopora was a dominant reef front genus in Curaçao, although it has yet to be found elsewhere in the Caribbean.

The assemblage marks a pivotal period in the turnover of the Caribbean coral fauna, where species which would persist into modern reefs co-occurred with species and genera which would become extinct due to environmental changes associated with closure of the Central American Isthmus. It is not only important to unravelling Caribbean extinctions, but also to predicting the fate of Isopora in the Pacific under changing oceanic conditions.

\section{References}

Budd AF, Wallace CC (2008) First record of the Indo-Pacific reef coral genus Isopora in the Caribbean region: two new species from the Neogene of Curaçao, Netherlands Antilles. Palaeontology 51:1387-1401

Budd AF, Peterson RA, McNeill DF (1998) Stepwise faunal change during evolutionary turnover: a case study from the Neogene of Curaçao, Netherlands Antilles. Palaois 13:167-185

Wallace CC, Chen CAC, Fukami H, Muir PR (2007) Recognition of separate genera within Acropora based on new morphological, reproductive, genetic evidence from A. togianensis, elevation of the subgenus Isopora Studer, 1878 to genus (Scleractinia: Astrocoeniidae; Acroporidae). Coral Reefs 26:231-239

C. C. Wallace $(\bowtie)$

Museum of Tropical Queensland, Townsville, QLD 4810, Australia

e-mail: carden.wallace@qm.qld.gov.au

\section{A. F. Budd}

Department of Geoscience, University of Iowa, Iowa City, IA 52242, USA

e-mail: ann-budd@uiowa.edu

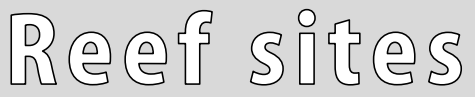

Coral Reefs (2009) 28:715

DOI $10.1007 / \mathrm{s} 00338-009-0495-7$ 